\title{
INDUSTRI KREATIF, MEDIA SOSIAL, DAN MINAT BERWIRAUSAHA: SINERGI MENUJU PEMBANGUNAN BERKELANJUTAN
}

\author{
M.Rachman Mulyandi ${ }^{1}$, Veny Anindya Puspitasari ${ }^{2}$ \\ ${ }^{I}$ Manajemen,Universitas Matana, Tangerang, rachman.mulyandi@matanauniversity.ac.id \\ ${ }^{2}$ Manajemen,Universitas Matana, Tangerang, veny.anindya@matanauniversity.ac.id
}

\begin{abstract}
ABSTRAK:
Pengembangan industri kreatif amat penting mengingat perannya yang signifikan dalam perekonomian Indonesia.Industri kreatif dapat berkembang di tangan generasi muda yang memiliki jiwa wirausaha dan didukung dengan penggunaan media sosial yang masif belakangan ini.Oleh karenanya, penelitian ini bertujuan untukmenganalisis pengaruh media sosial terhadap minat berwirausaha pada generasi muda sebagai pengembang industri kreatif yang potensial. Hal ini nantinya akan berdampak pada pembangunan yang berkelanjutan dalam kaitannya dengan penciptaan lapangan pekerjaan. Penelitian ini menggunakan analisis regresi sederhana yang hasilnya memperkuat hipotesis yang menyatakan bahwa media sosial mempengaruhi minat berwirausaha di kalangan generasi muda.Hasil ini membawa implikasi pada pentingnya peranan Perguruan Tinggi dalam mengembangkan kurikulum mengenai kewirausahaan dengan menambah porsi untuk praktek kewirausahaan serta menambahkan mata kuliah yang terkait dengan pemasaran digital.
\end{abstract}

Kata Kunci: industri kreatif, sosial media, minat berwirausaha, pembangunan berkelanjutan, regresi linier sederhana

\begin{abstract}
:
The development of the creative industry is very important given its significant role in the Indonesian economy. Creative industries can develop in the hands of young people who have entrepreneurial spirit and are supported by the use of massive social media lately. Therefore, this study aims to analyze the influence of social media on entrepreneurial interest in the younger generation as potential creative industry developers. This will have an impact on sustainable development in relation to job creation. This study uses a simple regression analysis, the results of which strengthen the hypothesis that social media influences the interest in entrepreneurship among the younger generation. These results have implications for the importance of the role of universities in developing curriculum on entrepreneurship by adding portions to entrepreneurial practices and adding courses related to digital marketing.
\end{abstract}

Keywords: Font type Times News Roman, size 12pt and number of keywords not more than 5 keywords. 


\section{National Conference of Creative Industri: \\ Sustainable Tourism Industri for Economic Development}

Universitas Bunda Mulia, Jakarta, 5-6 September 2018

e-ISSN No: 2622-7436

\section{PENDAHULUAN}

Rencana pembangunan suatu Negara amat penting guna menentukan arah kebijakan pembangunan yang dijadikan acuan bagi pelaksanaan pembangunan di seluruh wilayah Indonesia.Rencana Pembangunan Jangka Menengah Nasional (RPJMN) 2015-2019 merupakan salah satu rencana pembangunan yang dimiliki pemerintah saat ini.Dalam pelaksanaan pembangunannya, pemerintah menjumpai banyak permasalahan. Tingkat ketergantungan yang tinggi kepada sektor ekstraksi sumber daya alam (mineral dan perkebunan) menjadikan sektor lain sulit untuk berkembang (Hamdan, 2016). Selain itu, kemiskinan, pengangguran, dan kesenjangan pendapatan masih menjadi isu pokok yang perlu mendapat perhatian untuk segera diselesaikan.Dengan adanya fakta-fakta empiris tersebut, pemerintah merasa perlu untuk melakukan diversifikasi sumber-sumber pertumbuhan ekonomi nasional.Salah satu bentuk diversifikasi adalah pengembangan industri kreatif agar dapat menjadi tulang punggung ekonomi nasional.

Industri kreatif merupakan kegiatan usaha yang fokus pada kreasi dan inovasi. Saat ini industri kreatif masih potensial untuk dikelola karena Indonesia kaya akan budaya serta tradisi yang bisa menjadi sumber kreativitas (Kemenperin, 2018). Kreativitas itu akan dapat dikembangkan terutama oleh orang yang memiliki jiwa kewirausahaan. Hal ini dikarenakan seorang yang memiliki jiwa kewirausahaan mutlak untuk memiliki sikap disiplin, komitmen tinggi, jujur, mandiri, realistis, serta kreatif dan inovatif (Theresia, 2010).

Seorang dengan jiwa kewirausahaan saat ini sangat mungkin mengembangkan industri kreatif karena banyak peluang muncul.Bonus demografi adalah salah satu peluangnya. Pada tahun 2030 jumlah penduduk usia produktif diperkirakan di atas $40 \%$ dan 27\% di antaranya adalah penduduk muda dengan rentang usia 16-30 tahun. Penduduk muda tersebut berpeluang untuk menjadi creative class. Peluang berikutnya adalah perkembangan gaya hidup digital dimana akses teknologi informasi dan komunikasi sudah menjangkau lebih dari $90 \%$ penduduk Indonesia. Peningkatan jumlah kelas menengah juga menjadi peluang untuk mengembangkan industri kreatif.Pada tahun 2030, diperkirakan 135 juta penduduk Indonesia akan memiliki penghasilan bersih (net income) di atas US\$ 3.600 sebagai konsumen di industri kreatif. Peningkatan konsumen ini terkait dengan peningkatan permintaan produk kreatif di pasar global terutama produk berbasis media dan ICT (content industri). Hal ini didukung dengan modal yang kita miliki berupa international cultural heritage, sertakekayaan dan keindahan alam sebagai "bahan baku" di industri kreatif (Hamdan, 2016).

Dari berbagai peluang yang ada, perkembangan teknologi informasi menjadi peluang yang paling nyata dihadapi saat ini. Perkembangan industri kreatif dan perkembangan sektor digital berjalan seiringan dimana pada tahun 2019 diperkirakan pertumbuhan industri kreatif adalah sebesar $12 \%$ dan pengguna internet akan mencapai $51,8 \%$ dari total penduduk Indonesia (Lina, 2018). Perkembangan digital ini terlihat dari tumbuhnya pengguna layanan data. Menurut sebuah lembaga riset, We Are Social, total pengguna ponsel di Indonesia pada tahun 2015 mencapai 125 persen atau ekuivalen dengan 318,5 juta nomor dari total populasi penduduk Indonesia yang mencapai 255,5 juta orang. Total jumlah pengguna internet di Indonesia per November 2015 mencapai 88,1 juta orang. Angka ini merepresentasikan 34 persen dari total penduduk. We Are Social juga merilis data total pengguna aneka platform media sosial seperti Facebook, 


\section{National Conference of Creative Industri: \\ Sustainable Tourism Industri for Economic Development}

Universitas Bunda Mulia, Jakarta, 5-6 September 2018 e-ISSN No: 2622-7436

Instagram, Twitter, dan Path di Indonesia mencapai 79 juta orang atau 31 persen dari total populasi penduduk (Lina, 2018).

Pertumbuhan pengguna platform media sosial membuat banyak orang terpacu ide kreatifnya untuk mencari sumber penghasilan. Mereka memasarkan aneka produk kreatif dengan memanfaatkan jejaring pertemanan yang mereka miliki. Beragam produk, mulai dari fashion \& apparel, aksesoris, sampai makanan dalam kemasan, bahkan bibit tanaman dan binatang piaraan (pet) ditawarkan di sana. Hal serupa juga dengan mudah kita temukan di platform mobile social seperti BlackBerry Messenger atau Whatsapp.Dengan demikian jelas terlihat bahwa peranan media sosial di dalam industri kreatif berpengaruh kepada tumbuhnya minat kewirausahaan seseorang.

Semakin bertumbuhnya jumlah wirausaha di suatu Negara, akan berdampak pada terciptanya lapangan kerja baru terutama pada sektor riil. Hal ini juga mendukung program pembangunan berkelanjutan yang salah satu dari 17 tujuannya adalah mendorong pertumbuhan ekonomi yang terus menerus, inklusif, dan berkelanjutan, serta kesempatan kerja penuh, produktif dan pekerjaan yang layak bagi semua orang.

\section{Tujuan Penelitian}

Penelitian ini bertujuan menganalisis pengaruh media sosial terhadap minat berwirausaha pada generasi muda sebagai pengembang industri kreatif yang potensial.

\section{TINJAUAN PUSTAKA}

\section{Media Sosial}

Menurut Zarella (dalam Wardhana, 2015) media sosial adalah situs yang menjadi tempat orang-orang berkomunikasi dengan teman-teman mereka yang mereka kenal di dunia nyata dan dunia maya.Media sosial merupakan media online yang mendukung interaksi sosial. Sosial media menggunakan teknologi berbasis web yang mengubah komunikasi menjadi dialog interaktif. Adapun media sosial yang populer saat ini antara lain : Blog, Twitter, Facebook, Instagram, Path dan lain sebagainya.

Dalam Communication Works, media sosial memiliki ciri-ciri sebagai berikut :

1. Pesan yang disampaikan tidak hanya untuk satu orang saja namun bisa ke berbagai banyak orang.

2. Pesan yang disampaikan bebas, tanpa harus melalui suatu Gatekeeper.

3. Pesan yang disampaikan cenderung lebih cepat dibanding media lainnya.

4. Penerima pesan yang menentukan waktu interaksi.

Dari uraian diatas dapat disimpulkan bahwa media sosial merupakan media interaksi antara seseorang dengan orang lainnya yang dilakukan secara online tanpa batas ruang dan waktu. Menurut pendapat Chris Heuer dalam (Anugratami dkk., 2015) terdapat 4C dalam mengoperasikan sosial media yaitu :

1. Context yang meruapakan cara atau bentuk dalam menyampaikan suatu pesan kepada khalayak.

2. Communication yang merupakan praktek dalam menyampaikan, membagikan dan juga mendengarkan, merespon dan mengembangkan pesan kepada khalayak.

3. Collaboration yang merupakan bekerja besama-sama antara pemberi dan penerima pesan agar pesan yang disampaikan lebih efektif dan effisien.

4. Connection yang merupakan hubungan yang terjalin dan terbina antara pemberi dan penerima pesan. 


\section{Wirausaha}

Istilah wirausaha berasal dari kata entrepreneur (bahasa Perancis) yang diterjemahkan ke dalam bahasa inggris dengan arti between atau go-between. Menurut Suryana (2013), kewirausahaan merupakan suatu disiplin ilmu yang mempelajari tentang nilai, kemampuan dan perilaku seseorang dalam menghadapi tantangan hidup dan cara memperoleh peluang dengan berbagai resiko yang mungkin dihadapinya. Dengan kata lain, dapat disimpulkan bahwa wirausaha merupakan aktor atau orang yang bertanggung jawab dalam kegiatan memperoleh peluang dengan berbagai resiko.

\section{Minat Berwirausaha}

Menurut Yanto (dalam Arum, 2014), minat wirausaha adalah kemampuan untuk memberanikan diri dalam memenuhi kebutuhan hidup serta memecahkan permasalahan hidup, memajukan usaha atau menciptakan usaha baru dengan kekuatan yang ada pada diri sendiri. Dengan kata lain minat wirausaha dapat diartikan pula sebagai ketersediaan seseorang melakukan usaha untuk memperbaiki kualitas hidup.

Menurut Bhandari (dalam Praswati, 2014), variabel dan indikator untuk mengukur minat wirausaha adalah sebagai berikut:

1. Keinginan menjadi bos, memiliki beberapa indikator yaitu:

-Keinginan mempunyai usaha sendiri

-Keinginan bebas mengelola usaha sendiri

-Ingin bisa mengembangkan usaha sendiri

2. Tantangan Pribadi, memiliki indikator-indikator yaitu:

-Senang hal-hal yang bersifat kreatif

-Keinginan membuat sesuatu yang berbeda dari yang lain

-Senang melakukan hal-hal baru

-Mampu melakukan apa yang orang lain bisa lakukan

3. Fleksibilitas, memiliki indikator-indikator yaitu:

-Senang dengan pekerjaan yang waktunya tidak mengikat

4. Keuntungan, memiliki indikator-indikator yaitu :

-Keinginan bebas menjalankan keuangan usaha sendiri

-Keinginan merasakan kekayaan atas usaha sendiri

\section{Penelitian Terdahulu}

Ismail (2014) melakukan penelitian yang berjudul Pengaruh Media Sosial Terhadap Minat Mahasiswa untuk Berwirausaha.Dari penelitian tersebut diperoleh hasil bahwa ada pengaruh positif dan signifikan antara peran media sosial terhadap minat wirausaha.Hasil ini sejalan dengan hasil penelitian yang dilakukan oleh Nordiana (2016) yang berjudul Peran Jejaring Sosial sebagai Media Peningkat Minat Berwirausaha Mahasiswa untuk Berbisnis Online.Penelitian Nordiana ini memberikan penekanan pada jenis usaha yang ingin dijalankan oleh para mahasiswa, yaitu usaha yang berbasis online.

Yasundari (2016) dalam penelitiannya mengarahkan jenis media sosial yang digunakan oleh para responden, yaitu Instagram.Hal ini dikarenakan penggunaan Instagram yang cukup massif di Indonesia. Dalam penelitiannya yang berjudul Hubungan Penggunaan Instagram dengan Motivasi Wirausaha Pebisnis Daring dalam Meningkatkan Produktivitas diperoleh hasil bahwa penggunaan media sosial Instagram memiliki hubungan yang signifikan cenderung kuat dengan motivasi wirausaha pebisnis 
daring. Sedangkan penggunaan media sosial Instagram memiliki hubungan yang signifikan cenderung sedang dengan peningkatan produktivitas.

\section{METODE PENELITIAN}

Dalam penelitian ini, metode analisis yang digunakan adalah regresi linier sederhana.Regresi linier berganda adalah hubungan secara linear antara satu variabel independen (media sosial) dengan variabel dependen (minat berwirausaha). Analisis ini untuk mengetahui arah hubungan antara variabel independen dengan variabel dependen apakah positif atau negatif dan untuk memprediksi nilai dari variabel dependen apabila nilai variabel independen mengalami kenaikan atau penurunan..Data yang digunakan biasanya berskala interval atau rasio.

Rumus regresi linear sederhana sebagai berikut:

$\mathrm{Y}^{\prime}=\mathrm{a}+\mathrm{bX}$

Keterangan:

$Y^{\prime}=$ Variabel dependen (nilai yang diprediksikan)

$\mathrm{X}=$ Variabel independen

a $=$ Konstanta (nilai $\mathrm{Y}^{\prime}$ apabila $\mathrm{X}=0$ )

$\mathrm{b}=$ Koefisien regresi (nilai peningkatan ataupun penurunan)

\section{Populasi}

Populasi dalam penelitian ini adalah seluruh mahasiswa yang kuliah di Perguruan Tinggi yang berlokasi di Serpong dan sedang atau sudah menempuh Mata Kuliah Kewirausahaan dengan sampel sebanyak 132 responden.

\section{HASIL PENELITIAN DAN PEMBAHASAN}

\section{Hasil Analisa Data}

a. Uji Normalitas

Tabel 1- Keputusan Uji Normalitas Data

\begin{tabular}{|c|c|c|c|}
\hline Variabel & $\begin{array}{c}\text { Nilai Asymp. Sig. (2- } \\
\text { tailed) }\end{array}$ & Signifikansi & Keputusan \\
\hline Media Sosial & 0.062 & 0.05 & Normal \\
\hline Minat & 0.054 & 0.05 & Normal \\
\hline
\end{tabular}

Dari hasil uji dengan One Sample Kolmogrov-smirnov diperoleh angka probabilitas atau Asymp. Sig. (2-tailed) untuk variabel media sosial dan minat berwirausaha masingmasing sebesar 0.062 dan 0.054.Kedua nilai tersebut lebih besar jika dibandingkan dengan nilai probabilitas $5 \%$ sehingga data dikatakan terdistribusi normal.

\section{b. Regresi Linier Sederhana}

\section{Tabel 2- Koefisien Korelasi}

\begin{tabular}{|l|l|l|l|l|}
\hline Model & R & R Square & Adjusted R Square & $\begin{array}{l}\text { Std. Error of the } \\
\text { Estimate }\end{array}$ \\
\hline 1 &, $792^{\mathrm{a}}$ &, 628 &, 608 & 2,839 \\
\hline
\end{tabular}


a. Predictors: (Constant): Media Sosial

b. Dependent Variable: Minat

Nilai R (koefisien korelasi) sebesar 0,792 dapat diinterpretasikan bahwa hubungan kedua variabel penelitian berada pada kategori kuat.Hal ini didasarkan oleh pedoman untuk memberikan interpretasi koefisien korelasi sebagai berikut.

$0,00-0,199=$ sangat rendah

$0,20-0,399=$ rendah

$0,40-0,599=$ sedang

$0,60-0,799=$ kuat

$0,80-1,000=$ sangat kuat (Sugiyono, 2016)

Sedangkan nilai $\mathrm{R}^{2}$ sebesar 0,628 menunjukkan sumbangan variabel media sosial dalam mempengaruhi minat berwirausaha adalah sebesar $62,8 \%$ sedangkan sisanya sebesar 37,2\% dipengaruhi oleh variabel lain di luar model penelitian.

\section{c. Uji Hipotesis}

\section{Tabel 3- Hasil Uji Hipotesis}

\begin{tabular}{|c|c|c|c|c|c|}
\hline \multirow{2}{*}{ Model } & \multicolumn{2}{|c|}{$\begin{array}{c}\text { Unstandardized } \\
\text { Coefficients }\end{array}$} & $\begin{array}{c}\text { Standardized } \\
\text { Coefficients }\end{array}$ & & Sig. \\
\cline { 2 - 5 } & B & Std. Error & Beta & t &, 000 \\
\hline 1 (Constant) & 22,153 & 3,496 & & 6,337 &, 002 \\
\hline Media Sosial &, 303 &, 096 &, 266 & 3,146 & a \\
\hline
\end{tabular}

Hasil perhitungan koefisien regresi sederhana menunjukkan nilai koefisien konstanta adalah sebesar 22,153 dan koefisien variabel bebas adalah sebesar 0,303. Dari kedua nilai tersebut dapat dibuat persamaan regresi $Y=22,153+0,303 X$. Nilai positif yang terdapat pada koefisien regresi variabel bebas menggambarkan bahwa arah hubungan antara variabel bebas dan variabel terikat adalah searah.

Dengan menggunakan hipotesis:

Ho = tidak ada pengaruh antara media sosial terhadap minat berwirausaha

$\mathrm{Ha}=$ ada pengaruh antara media sosial terhadap minat berwirausaha

dapat dikatakan bahwa terdapat pengaruh antara media sosial terhadap minat berusaha karena nilai t hitung sebesar 3,146 lebih besar dari pada nilai t tabel sebesar 1.97838.

Sedangkan dengan hipotesis:

Ho = nilai sig. $>0,05$ maka media sosial tidak berpengaruh signifikan terhadap minta berwirausaha

$\mathrm{Ha}=$ nilai sig. $<0,05$ maka media sosial berpengaruh signifikan terhadap minta berwirausaha

dapat dikatakan bahwa media sosial mempengaruhi minat berwirausaha secara signifikan karena karena memiliki nilai signifikansi sebesar 0,002.

\section{Pembahasan}

Dari hasil analisa data dapat disimpulkan bahwa media sosial berpengaruh cukup kuat dan signifikan terhadap tumbuhnya minta berwirausaha di kalangan generasi muda.Sebagai implikasinya, amat perlu bagi sebuah Perguruan Tinggi untuk meninjau kembali kurikulumnya terutama terkait dengan pengembangan Kewirausahaan.Adanya Mata Kuliah Kewirausahaan tidak hanya menjadi suatu kewajiban tanpa upaya 


\section{National Conference of Creative Industri: \\ Sustainable Tourism Industri for Economic Development}

Universitas Bunda Mulia, Jakarta, 5-6 September 2018 e-ISSN No: 2622-7436

pengembangan jiwa di dalam diri mahasiswa, melainkan menjadikannya suatu kebutuhan di dalam diri mereka.

Menumbuhkan jiwa kewirausahaan di dalam diri mahasiswa dapat dilakukan dengan memberikan ruang yang lebih untuk kegiatan praktek.Asmawan (2017) melalui penelitiannya menyatakan bahwa dengan mengikuti praktek kewirausahaan, mahasiswa jadi memiliki keberanian dan kepercayaan diri untuk memulai suatu usaha.Secara efektif, mahasiswa menunjukkan rasa senangnya dalam melakukan suatu usaha dan secara konotatif menunjukkan motivasinya untuk tetap melakukan usaha.

Namun demikian, praktek saja tidak cukup untuk memupuk jiwa kewirausahaan dalam diri mahasiswa. Mata Kuliah Kewirausahaan perlu didukung oleh mata kuliah lain seperti Pemasaran Digital, Pemasaran Media Sosial, Search Engine Optimization, dan mata kuliah lain yang terkait dengan kewirausahaan. Dalam konteks lingkup penelitian pada mahasiswa di Serpong, dari mereka diperoleh informasi bahwa tidak semua Perguruan Tinggi memiliki mata kuliah-mata kuliah tersebut.Kebanyakan Perguruan Tinggi hanya sebatas memberikan ruang untuk praktek kewirausahaan sehingga "bekal" bagi mahasiswanya untuk terjun langsung untuk berwirausaha masih kurang.Hal ini dikarenakan dari hasil penelitian yang menyatakan bahwa media sosial kuat dalam mempengaruhi timbulnya minat berwirausaha.

Seperti pada pemaparan di bagian awal, perkembangan media sosial memicu berkembangnya industri kreatif melalui wirausaha. Dengan demikian, apabila Perguruan Tinggi peka dengan perkembangan media sosial di masyarakat, maka akan berpotensi banyak melahirkan orang-orang yang akan mengembangkan industri kreatif.

\section{KESIMPULAN DAN IMPLIKASI}

Dari penjelasan pada bagian sebelumnya, dapat disimpulkan bahwa perkembangan industri kreatif amat dipengaruhi oleh jumlah wirausaha, terutama yang masih muda, yang dimiliki oleh suatu Negara.Namun demikian, menimbulkan minat untuk berwirausaha bukanlah suatu hal yang mudah. Salah satu yang mempengaruhi timbulnya minat untuk berwirausaha adalah dengan hadirnya media sosial.Dengan demikian, penting bagi Perguruan Tinggi untuk menyikapi hal ini dengan melakukan peninjauan kurikulum yang terkait dengan pengembangan jiwa kewirausahaan. Memberikan porsi lebih pada kegiatan praktek kewirausahaan dan menghadirkan mata kuliah yang terkait pemasaran melalui media sosial adalah beberapa cara yang dapat dilakukan oleh Perguruan Tinggi untuk mengembangkan jiwa kewirausahaan mahasiswanya.

\section{DAFTAR PUSTAKA}

Anugratami dkk.(2015). Pengaruh pengunaan media sosial twitter terhadap motivasi followerspada akun @ merryriana(periode 01 December 2014-17 Januari 2015).EProceeding of Management, 2(2), 2256-2261.

Arum, P.S. (2014).Minat berwirausaha pada siswa kelas xi jurusan tata boga di smk negeri 2 godean. Yogyakarta: Fakultas Ilmu Pendidikan Universitas Negeri Yogyakarta 


\section{National Conference of Creative Industri: \\ Sustainable Tourism Industri for Economic Development}

Universitas Bunda Mulia, Jakarta, 5-6 September 2018 e-ISSN No: 2622-7436

Asmawan, C. (2017). Dampak mata kuliah praktek kewirausahaan terhadap motivasi mahasiswa pendidikan akuntansi untuk berwirausaha. Makalah dipresentasikan dalam Seminar Nasional Pendidikan 2017

Hamdan (2016).Kebijakan dan Strategi Pengembangan Ekonomi Kreatif.Makalah dipresentasikan dalam kegiatan Study Excursie Mahasiswa Jurusan Ilmu Ekonomi dan Studi Pembangunan Universitas Muhammadiyah Malang

Ismail, A.R. (2014). Pengaruh media sosial terhadap minat mahasiswa untuk berwirausaha. Skripsi, Universitas Negeri Medan.

Kemenperin. 2018. Industri Kreatif Masih Potensial. Diakses pada 10 Agustus 2018, dari http://www.kemenperin.go.id/artikel/4060/Industri-Kreatif-Masih-Potensial

Lina.2018. Peluang Industri Kreatif Pada Era Digital. Diakses pada 10 Agustus 2018, dari http://bisnisbandung.com/2018/07/07/peluang-industri-kreatif-pada-eradigital/

Nordiana, E. (2016). Peran jejaring sosial sebagai media peningkat minat berwirausaha mahasiswa untuk berbisnis online.Jurnal Ilmiah Mahasiswa FEB, 2(2).

Praswati, A.N. (2014). Analisis faktor-faktor yang mempengaruhi minat wirausaha di kalangan mahasiswa studi kasus: fakultas ekonomi dan bisnis universitas muhammadiyah Surakarta. Jurnal Universitas Muhammadiyah Surakarta

Sugiyono (2016).Metodologi penelitian kuantitatif, kualitatif, dan $r \& d$. Bandung: CV Alfabeta

Suryana (2013).Kewirausahaan: kiat dan proses menuju sukses. Jakarta: Salemba Empat

Theresia.2010. Keterkaitan Antara Kewirausahaan dan Ekonomi Kreatif. Diakses pada 10 Agustus 2018, darihttps://feksi.wordpress.com/2010/10/24/keterkaitan-antarakewirausahaan-dan-ekonomi-kreatif/

Wardhana, A. (2015). Analisis faktor-faktor pembentuk service recovery pada top brand perusahaan penyedia jasa rental mobil di Indonesia berdasarkan persepsi pelanggan korporasi.Prosiding Seminar Nasional Penelitian dan Pengabdian pada Masyarakat Sosial, Ekonomi dan Humaniora, 15-22.

Yasundari (2016).Hubungan penggunaan instagram dengan motivasi wirausaha pebisnis daring (online) dalam meningkatkan produktivitas.Jurnal Kajian Komunikasi, 4 (2), 208-218.

\section{BIODATA}

M. Rachman Mulyandi lahir pada 21 Juni tahun 1982 di Jakarta.Ia menyelesaikan pendidikan sarjananya dari Universitas Pelita harapan (UPH) dengan jurusan manajemen. Kemudian setelah lulus sarjana ia melanjutkan pendidikan ke School of Bisnis Management (SBM) ITB dengan jurusan Bisnis Leadership. Saat ini ia sedang menempuh program doktoral di Universitas Trisakti dengan jurusan Service Manajemen. Pengalaman mengajar dimualai dari tahun 2011 di Universitas Raharja, kemudian 2013 di Universitas Multimedia Nusantara (UMN). Pada tahun 2015, ia mengajar di Universitas Matana sampai sekarang. Selain dibidang pendidikan, ia juga berpengalaman dibidang marketing, ia pernah menjadi manajer marketing di bidang properti dan Rumah Sakit. 
Veny Anindya Puspitasari lahir pada 12 Mei 1984 di Serang, Banten.Iamenyelesaikan pendidikan sarjananya dari Fakultas Ekonomi Jurusan Studi Pembangunan Universitas Sebelas Maret Surakarta pada tahun 2005. Pada 2006ia melanjutkan studi ke jenjang S2 di Fakulti Ekonomi dan Perniagaan Universiti Kebangsaan Malaysia dengan peminatan Moneter dan Keuangan. Pengalaman mengajarnya dimulai pada tahun 2008 di Lincoln College Malaysia. Pada 2010 ia kembali ke Indonesia dan mengajar di Universitas Bunda Mulia Jakarta hingga 2018. Saat ini ia mengajar di Universitas Matana Tangerang. Dalam kapasitasnya sebagai dosen, Veny juga memiliki ketertarikan pada industri pasar modal.Ketertarikannya ini membawanya untuk memperoleh sertifikasi sebagai Wakil Perantara Pedagang EFek (WPPE) dan sebagai analis saham (Certified Securies Analyst). 